\title{
Pesticide Use in Cereals: An Analysis of Farmers' Perception and Knowledge in Jammu District
}

\author{
Rakesh Kumar $^{1 *}$, Pawan Kumar Sharma ${ }^{2}$, P.S. Slathia ${ }^{1}$ and Nishi Sharma ${ }^{3}$
}

${ }^{1}$ Division of Agricultural Extension Education, Faculty of Agriculture, Sher-e-Kashmir

University of Agricultural Sciences and Technology -Jammu, India

${ }^{2}$ Krishi Vigyan Kendra-Kathua, SKUAST-J, India

${ }^{3}$ Division of Veterinary Parasitology, Faculty of Veterinary Science and Animal Husbandry, Sher-e-Kashmir University of Agricultural Sciences and Technology -Jammu, India

*Corresponding author

\begin{tabular}{|c|c|}
\hline & A B S T R A C T \\
\hline & $\begin{array}{l}\text { In agriculture, the use of pesticide has been the dominant form of pest management since } \\
\text { the 1950s to kill pest organisms including insects, weeds, fungi and nematodes. In recent } \\
\text { times, use of pesticides in rice and wheat cultivation has increased rapidly and this } \\
\text { scenario contributes significantly towards adverse effects on human health, environment }\end{array}$ \\
\hline $\begin{array}{l}\text { Ke y w o r d s } \\
\text { Pesticides, } \\
\text { Perception, } \\
\text { Knowledge, } \\
\text { Productivity. }\end{array}$ & $\begin{array}{l}\text { India and study area. Keeping this in view a study was undertaken in R.S. Pura tehsil of } \\
\text { Jammu district of Jammu and Kashmir with the objective to analyze the farmer's } \\
\text { perception and knowledge regarding pesticide use in two major cereal crops i.e. rice and } \\
\text { wheat grown in Jammu district. Eight villages from the selected tehsil were randomly }\end{array}$ \\
\hline Article Info & $\begin{array}{l}\text { selected and a list of } 20 \text { farmers growing rice and wheat was prepared for each village. } \\
\text { Eight farmers out of } 20 \text { were then randomly selected from each village thus comprising a }\end{array}$ \\
\hline $\begin{array}{l}\text { Accepted: } \\
\text { 21 September } 2017 \\
\text { Available Online: } \\
10 \text { October } 2017\end{array}$ & $\begin{array}{l}\text { sample of } 64 \text { respondents for final study. The gain in terms of increased yield with } \\
\text { herbicide use, as observed by farmers was reported to be } 3.0 \mathrm{q} / \mathrm{ha} \text {, and } 2.0 \mathrm{q} / \mathrm{ha} \text { in rice and } \\
\text { wheat, respectively. The gain with use of insecticides was found to be } 0.50 \mathrm{q} / \mathrm{ha} \text { for rice. } \\
\text { Farmers were found to be well aware about ill effects of pesticides and ready to use }\end{array}$ \\
\hline & $\begin{array}{l}\text { alternatives carrying less hazards, it found equally eftective. Farmers had good knowledge } \\
\text { about name and dosages of different herbicides used in rice and wheat crop but lack } \\
\text { knowledge about different insecticides and fungicides used in these crops because of its } \\
\text { less use in both these important cereal crops. }\end{array}$ \\
\hline
\end{tabular}

\section{Introduction}

Pesticides are an integral part of present Indian agriculture which has shifted its course from sustenance to commercial character. This has resulted in exposing cereal crops to regular use of pesticides even in remote districts of the country. However, cereals now are also exposed to pesticide use. Indian pesticide market is the $12^{\text {th }}$ largest in the world and stands first in Asian continent. India produces 90,000 metric tonnes of pesticides in a year with over 400 million acres under cultivation and over $60 \%$ of the country population depends upon agriculture as well as the country's economy mainly depends on the agriculture (Jana, 2013). The use of pesticides in cereals emphasized the 
importance of technical knowledge that farmers must acquire to reduce the negative effects of pesticides on different natural resources such as soil, water, environment as well on human health. Adequate knowledge of pesticide use is must on the part of farmers for promoting its rational use for sustainable agriculture. Indiscriminate use of pesticides has led to many problems like adverse effects on parasites, predators and pollinators, toxic residues, resurgence of treated population of pests, development of resistance in insects to insecticides, environmental population etc. (Lal, 2001). Pesticides pose serious threats to both human health and the environment. However, farmers and agricultural scientists have now to deal with a paradox: due to a rapidly-growing population and to the lack of availability of new farmland, it will be necessary to continue to increase crop yields in the future (Foley et al., 2011). On the other hand, it is necessary to reduce the harmful effect of pesticides on human health and on the environment (Ensirnk et al., et al., 2013).

Several studies have shown that exposure to pesticides poses serious threats to human health of both professional (especially farmers) and rural populations (Elbaz, 2009). Rice crop plays a significant role in livelihood of people of $\mathrm{J} \& \mathrm{~K}$. It is the staple food and second important crop of the state (Trag and Rather, 2013). In Jammu division rice is grown on an area of 116.000 ha and wheat on an area of 247.000ha. (DES, 2013-14). In $\mathrm{J} \& \mathrm{~K}$ pesticide use by weight (a.i) has increased exponentially from 142 MT $90.155 \mathrm{~kg} / \mathrm{ha})$ in $1994-95$ to $1711 \mathrm{MT}(2.410$ $\mathrm{kg} / \mathrm{ha}$ ) in 2011-12 (Directorate of Plant Protection Quarantine and Storage, GOI) which is an increase of $1105 \%$ with a slope of 217.5tonnes/year $\left(\mathrm{R}^{2}=0.69\right)$ (Peshin et al., 2014). Further knowledge of the farming community about different agricultural technologies including plant protection technology plays a crucial role in judicious use of different pesticides. Knowledge of the recommended technologies is a pre-requisite to adoption process. The basic input for achieving higher productivity in the assimilation of technological knowledge is one of the important components of behaviour. Knowledge of the technology is the basic requirement as it gives impetus to adopt a technology. Thus a study was undertaken to analyze farmer's perception and knowledge about pesticide use in two major cereal crops grown in Jammu district.

\section{Materials and Methods}

R.S. Pura tehsil of Jammu district is an agricultural active tehsil was purposively selected for conducting the present study with the objective to assess the extent of pesticide use in cereals particularly rice and wheat and for assessing the perception and knowledge of farmers regarding pesticide use. Eight villages from the selected tehsil were randomly selected and a list of 20 farmers was prepared for each village. Eight farmers out of 20 were then randomly selected from each village thus comprising a sample of 64 respondents and data were collected on pre-structured schedule framed for the present study in the year 201415. The recommended plant protection technology regarding dosages of different pesticides used in the cultivation of rice and wheat crop of SKUAST-Jammu for the study area is as follows in table 1. Thereafter comparison was made between actually used dosages by farmers and recommended level of dosages of different pesticides in rice and wheat crop. The data collected were put to tabulation and percentages were calculated for deriving the conclusion. Further the average land holding size of the respondent farmers taken for assessing their perception and knowledge about different plant protection chemicals was 1.34 ha. Knowledge of farmers was assessed regarding names and dosages of different herbicides, insecticides and fungicides used in production of rice and wheat crop only. 


\section{Results and Discussion}

\section{Descriptive statistics of respondent farmers}

Data presented in table 2 show descriptive statistics of important socio-personal variables of respondent farmers. Average age of respondent farmers was 55.04years with S.D of 12.82. Average number of years of education completed was 9 years which indicates medium level of educational status of sampled farmers. Average land holding size of farmers was 1.34 ha with standard deviation of 1.04 which is higher than state average land holding size of $0.76 \mathrm{ha}$.Average farming experience was 33.25 years, average number of source of information utilized by the respondent farmers was almost two and also average distance of almost $2 \mathrm{~km}$ from the nearest pesticide retailer shops which indicates the presence of good input facilities in the study area.

Frequency of herbicide use pattern in rice and wheat crop $n=64$ (Multiple response)

Post emergence herbicides used by the farmers in both rice and wheat crop respectively as analyzed in table 3 . The frequency of spraying herbicides was higher in rice as compared to wheat as $39 \%$ of farmers reported to use weedicide spray twice for controlling both pre-emergence and post emergence weeds thus reflecting the menace of weed problem hampering the production of rice crop. $77 \%$ and $72 \%$ of farmers used recommended dosages of herbicides in rice and wheat crop.

Adoption status of fungicides, insecticides and storage pesticides in rice and wheat crop

Analysis of data given in table 4 shows that $31 \%$ and $53 \%$ of farmers used fungicides as seed treatment in wheat and rice crop respectively. $23 \%$ and $41 \%$ farmers in study used fungicides only once where as $20 \%$ and $22 \%$ farmers used fungicides two time during different stages of crop growth for protecting their crops from attack of different diseases. Only $8 \%$ farmers used insecticide in rice crop and all of them applied less than the recommended dosages (Rates of recommended dosages is given in table 1).

\section{Effect of pesticide use on average yield of} rice and wheat crops as perceived by farmers

Data presented in table 5 reveals the physical benefits arising out of pesticide use in rice and wheat crop, as perceived by the respondents in the study area. The gain in terms of increased yield with herbicide use, as observed by farmers was found to be $9.35 \mathrm{q} / \mathrm{ha}$ \& 9.0q/ha paddy and wheat respectively.

The gain with use of insecticides was found to be $0.50 \mathrm{q} / \mathrm{ha}$ for rice crop. The gain in yield with use of fungicides was found to be 1.0 $\mathrm{q} / \mathrm{ha}$ for rice and wheat respectively. The gain in yield with use of rodenticides was found to be $0.80 \mathrm{q} / \mathrm{ha} \& 1.00 \mathrm{q} / \mathrm{ha}$ for basmati rice, and wheat respectively. Farmers were of view that store pests cause damage to the tune of 5\% of total stored wheat in absence of its use in wheat crop and with the use of storage pesticides they save their stored wheat from this damage. India's $30 \%$ potential crop yield is damaged by the attack of insect-pests, diseases, weeds and rodents (Jana, 2013). The change in yield in rice and wheat crop with and without use of different pesticide as reported by the farmers was based on their experience of farming. Farmers in study area reported that sometimes they fail to apply different pesticides in some cropped area in both rice and wheat crop due to lack of certain conditions such as proper moisture in the field, adverse weather conditions etc. required for the application of different pesticides and 
this situation provides them an opportunity to quantify and compare the yield of pesticides used and non-pesticides used fields and on this basis different yield figures of rice and wheat crop were calculated for the present study as shown in table 5 .

Further productivity data particularly of basmati paddy of herbicides used and non - used farmer's fields put to statistical analysis by applying paired two sampled independent $\mathrm{t}$-test which gave $\mathrm{t}$-value equal to- 43.21 and p-value equal to 0.000 which suggests that there is significant impact of herbicides use on productivity of paddy crop. In case of wheat crop also there is significant impact of herbicides on the productivity of wheat crop as indicated by $\mathrm{p}$-value which is 0.000 .

Table.1 Recommended plant protection technology

\begin{tabular}{|c|c|c|c|c|}
\hline \multirow[t]{2}{*}{ S.No } & \multirow[t]{2}{*}{ Name of pesticides } & & \multicolumn{2}{|c|}{ Recommended dosages } \\
\hline & & & Paddy & Wheat \\
\hline 1. & $\begin{array}{l}\text { Fungicide } \\
\text { Technical name } \\
\text { Carboxin or carbondiazem } \\
\text { for seed treatment } \\
\text { Propiconazole,Tebuconazole, } \\
\text { Mancozeb }\end{array}$ & $\begin{array}{l}\text { Trade } \\
\text { name } \\
\text { Thiram } \\
\text { Tilt }\end{array}$ & - & $\begin{array}{l}2 \mathrm{gms} / \mathrm{kg} \text { of seed } \\
0.1 \% \\
0.25 \%\end{array}$ \\
\hline 2. & $\begin{array}{l}\text { Insecticide } \\
\text { Imidachloropid200SL for } \\
\text { seed treatment } \\
\text { Lindane6G(soil treatment) } \\
\text { Aluminum phosphide for } \\
\text { Field rats as fumigants } \\
\text { Zinc phosphide }\end{array}$ & & & $\begin{array}{l}25 \mathrm{~kg} / \mathrm{ha} \\
\text { Two tablets of } 0.6 \mathrm{~g} / \mathrm{burrow} \\
\text { or } 3 \mathrm{~g} / \mathrm{burrow} \\
25 \mathrm{gms} \text { mixed with } 1 \mathrm{~kg} \\
\text { wheat or gram or maize flour } \\
\text { with vegetable oil and gur } \\
(1: 40) .5-6 \text { pellets per burrow. }\end{array}$ \\
\hline 3. & $\begin{array}{l}\text { Herbicides(post } \\
\text { emergence)s } \\
\text { Broad leaf weeds } \\
\text { Amine salt } \\
\text { Ethyl ester of 2,4-D } \\
\text { Monocot weeds } \\
\text { Isoproton } \\
\text { For both monocot \& Dicot } \\
\\
\text { Control of Phalaris minor } \\
\text { (sitti) Metribuzine (if not } \\
\text { controlled by isoproton) }\end{array}$ & & & $\begin{array}{l}0.75 \mathrm{~kg} \mathrm{a} . \mathrm{i} / \mathrm{ha} \\
0.5 \mathrm{~kg} \mathrm{a.i} / \mathrm{ha} \\
0.75 \mathrm{~kg} \mathrm{a.i} / \mathrm{ha} \\
0.75 \mathrm{~kg} \mathrm{a.i+2,4-D} \mathrm{of} \mathrm{ethyl} \\
\text { ester @ } 500 \mathrm{ml} / \mathrm{ha} \\
200 \mathrm{gms} \text { a.i } / \mathrm{ha} \text { in } 500-6001 \\
\text { of water }\end{array}$ \\
\hline
\end{tabular}


Table.2 Descriptive statistics of respondent farmers

\begin{tabular}{|c|c|c|}
\hline S.No & Parameters & Descriptive statistics \\
\hline 1 & Average age (in years) & $55.04( \pm 12.82)$ \\
\hline 2 & Average schooling years (in years) & $9.93( \pm 3.23)$ \\
\hline 3. & Average land holding size (ha) & $1.34( \pm 1.04)$ \\
\hline 4. & Average farming experience (in years) & $33.25( \pm 12.56)$ \\
\hline 5. & Average number of source of information & $1.62( \pm 0.60)$ \\
\hline 6. & Average distance from nearby pesticide dealer outlet (in kms) & $1.62( \pm 1.58)$ \\
\hline
\end{tabular}

Table.3 Frequency of herbicide use pattern in rice and wheat crop n=64 (Multiple response)

\begin{tabular}{|l|l|c|c|}
\hline S.No & Particulars & Paddy (\%age) & Wheat (\%age) \\
\hline 1. & Pre-emergence herbicide & 100 (After transplanting) & - \\
\hline 2. & Post emergence herbicides & 39 & 100 \\
\hline 3. & Frequency of spray & 100 & 100 \\
& a) One time & $39-$ & -- \\
& b) Two time & 8 & 16 \\
\hline 4. & Higher dosages & 16 & 12 \\
& Under dosages & 77 & 72 \\
\hline
\end{tabular}

Table.4 Adoption status of fungicides, insecticides and storage pesticides in rice and wheat crop

\begin{tabular}{|l|l|c|c|}
\hline S.No & Particulars & Paddy (\%age) & Wheat (\%age) \\
\hline 1. & Fungicide & 16 & 31 \\
& During seed treatment only & 8 & 12 \\
& During both seed treatment and in & 7 & 10 \\
& standing crop & 69 & 47 \\
& Only in standing crop & & 41 \\
& Never applied & 23 & 12 \\
& Frequency & 8 & 10 \\
& One time & & 17 \\
& Two time & 28 & 73 \\
\hline 2. & More than recommended & 22 & - \\
& Less than recommended & 50 & - \\
& Recommended dosages & & - \\
& Insecticide(Frequency of spray) & & - \\
& One time & & \\
& & - & \\
& & & \\
& More than recommended & - & \\
& Less than recommended & & \\
& Recommended dosages & & \\
\hline
\end{tabular}


Table.5 Effect of pesticide use on average yield of rice and wheat crops as perceived by farmers

\begin{tabular}{|l|c|c|}
\hline \multirow{2}{*}{ Type of Pesticides } & \multicolumn{2}{|c|}{ Crop wise average yield (q/ha) } \\
\cline { 2 - 3 } & Paddy (Basmati) & Wheat \\
\hline Herbicides & 29.78 & 24.79 \\
\hline With use & 20.43 & 15.79 \\
\hline Without use & 9.35 & 9.00 \\
Difference & -43.221 & -30.03 \\
t-value & $0.000^{*}$ & $0.000^{*}$ \\
p-value & Not used \\
\hline Insecticides & 25.00 & \\
\hline With use & \\
\hline Without use & 24.50 & 22.00 \\
\hline Fungicides & 25.00 & 21.00 \\
\hline With use & 24.00 & 22.00 \\
\hline Without use & 26.00 & 21.00 \\
\hline Rodenticides & 25.20 & \\
\hline With use &
\end{tabular}

Table.6 Perceived health hazards due to inadequate use of pesticides n=64 (Multiple response)

\begin{tabular}{|l|l|c|}
\hline S.No. & Health Hazards & \% age of farmers \\
\hline 1. & Skin irritation & 62 \\
\hline 2. & Headache & 86 \\
\hline 3. & Respiration problem & 31 \\
\hline 4. & Uneasiness & 48 \\
\hline 5. & Vomiting & 16 \\
\hline
\end{tabular}

Table.7 Opinion of farmers regarding pesticide use in agriculture (Multiple responses)

\begin{tabular}{|l|l|c|}
\hline S.No & Statements & \% age of farmers \\
\hline 1. & Pesticides are crucial in absence of other alternatives to control pests. & 94 \\
\hline 2. & Want to reduce use of pesticides in agriculture & 70 \\
\hline 3. & Want to control pests by using combination of different methods & 53 \\
\hline 4. & Aware about ill effects of excessive use of pesticides & 100 \\
\hline
\end{tabular}

Table.8 Knowledge about different aspect of pesticide use in rice and wheat crop

\begin{tabular}{|l|l|l|}
\hline Knowledge about & Paddy $(\mathbf{n}=64)$ & Wheat $(\mathbf{n}=64)$ \\
\hline Name of herbicides & $60(93.75)$ & $52(81.25)$ \\
\hline Dosages of herbicides & $44(68.75)$ & $40(62.5)$ \\
\hline Name of Insecticides & $7(10.93)$ & - \\
\hline Dosages of insecticides & $4(6.25)$ & - \\
\hline Name of Fungicides & $5(7.81)$ & $15(23.43)$ \\
\hline Dosages of fungicides & - & $9(14.06)$ \\
\hline
\end{tabular}


Fig.1 Different health hazards perceived by farmers

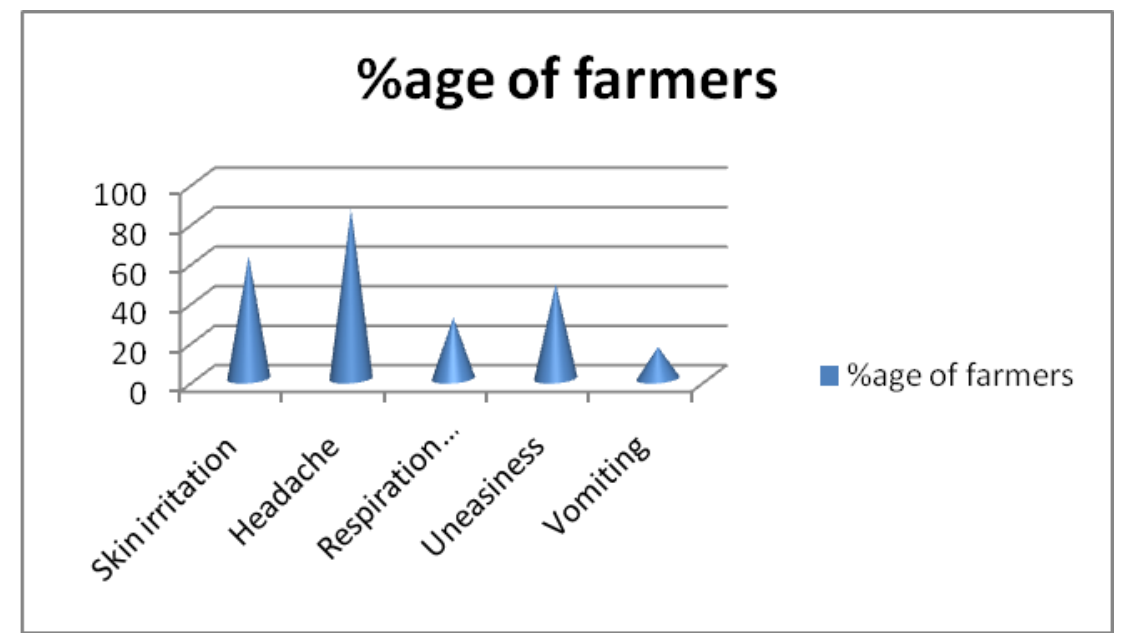

Perceived health hazards due to inadequate use of pesticides $n=64$ (multiple response)

Analysis of data presented in table 6 depicts that number of farmers felt health problems in course of pesticide application. The major clinical symptoms observed by the respondent farmers include headache $86 \%$ ) followed by skin irritation $62 \%$. The symptoms like uneasiness, respiration problem and vomiting were also observed in $48 \%, 31 \%$ and $16 \%$ of respondents respectively. This shows that inappropriate use and handling of pesticide can cause serious health hazards. Jana (2013) reported the same health problems being faced by vegetable growers in using pesticides. Snelder et al., (2008) also reported that the rapid increase in the application of pesticides has posed threats to the environment and adverse health effects on farmers.

\section{Opinion of farmers regarding pesticide use in agriculture}

Analysis of data given in table 7 shows that $100 \%$ farmers were found to be well aware about ill effects of pesticides and ready to use alternatives carrying less hazards, if found equally effective. About94\% farmers recognize pesticides as an integral part of their agricultural activities including cultivation of cereals. Further $53 \%$ of the farmers were also of the view that they want to control different pests limiting their successful crop cultivation by a combination of diverse means such as IPM, using traditional practices etc. Meena and Dudi (2014) also reported certain traditional practices for controlling different pests in wheat crop such as soaking wheat seeds in cow dung slurry, dusting of ash, tying white flags to scare rodents etc.

\section{Knowledge about different aspect of pesticide use in rice and wheat crop}

Knowledge about different pesticides used in paddy and wheat crop was analyzed in table 8 and it shows that farmers possessed fairly good knowledge about different herbicides used in paddy crop followed by wheat crop. $93.75 \%$ of sampled farmers had knowledge about names of different herbicides such as Butachlor, in wheat crop and among these only $68.75 \%$ had knowledge about different dosages of these herbicides. In case of wheat $81.25 \%$ farmers had knowledge about different herbicides used in wheat crop and only $62.5 \%$ had correct knowledge about 
dosages. Further very little knowledge possessed by the farmers regarding different insecticides and fungicides used in paddy and wheat crop. Data indicates that only $10.93 \%$ and $7.81 \%$ farmers had knowledge about names of different insecticides and fungicides to be used in paddy crop. Only $6.25 \%$ farmers had knowledge about dosages of insecticides and none of the farmers had knowledge about dosages of different fungicides used in paddy crop.

None of the sampled farmers had knowledge about name and dosages of insecticides used in wheat crop. As for as knowledge about different fungicides used in wheat crop is concerned $23.43 \%$ farmers had correct knowledge about name and $14.06 \%$ had knowledge about correct dosages of fungicides used in wheat crop. Thus it is concluded that majority of the respondents had knowledge of the herbicides to be applied against weeds in paddy and wheat crop, so the adoption was also on the higher side. This finding is in conformity with the study conducted by Sheikh et al., (2006) and Ragasa et al., (2013).

It is concluded from the above study that herbicides are an indispensable part of cereal cultivation. Weed infestation has been reported to largely affect the yield of cereal crops mainly rice and wheat crop under study. Use of insecticides and fungicides is negligible in the cultivation of rice and wheat crop. Farmers had good knowledge about recommended dose of different herbicides but vice-versa in case of fungicides and insecticides. Further farmers are well aware about ill effects of inadequate use of pesticides on different natural resources and on human health also and ready to use alternatives carrying less hazards, if found equally effective. Thus it is suggested that a comprehensive approach like IPM should be promoted in the study area for checking different type of pests in major cereal crops and for promoting rational use of pesticides for sustainable agriculture which may be less harmful for environment and bio-diversity. Farmer's knowledge should be enhanced through different means about different plant protection measures for better productivity. In this regard role of field extension functionaries becomes very critical. Literature on safe handling and use of pesticides in vernacular language should be developed and circulated among farming community. The present study can provide empirical feedback to plant protection scientists and agronomists regarding trend of use of different pesticides by the farmers in rice and wheat crop.

\section{Acknowledgement}

Authors highly acknowledge the concerned personnel of SKUAST-J, Agriculture Department, J\&K who provided the secondary data and farmers of the study area who cooperated very cordially in providing primary field data for the present study.

\section{References}

Bhardwaj, T., and Sharma J.P. 2015.IPM approach for healthy intensification of rice crop. A paper presented in VII seminar on Sustainable Rural Livelihood: $\quad$ Technological\& Institutional Perspective.8-10 January, SKUAST-Jammu

Directorate of Economics \&Statistics (DES), J\&K Govt.2013-14

Directorate of Plant Protection Quarantine and Storage, GOI 2011-12

Elbaz, A., 2009. Professional exposure to pesticides and Parkinson disease.Ann Neurol.66, 494-504

Enserink, M., Hines, P. J., Vignieri, S. N., Wigginton, N. S. and Yeston, J. S. 2013. The pesticide paradox. Science. Pp. 341, 729 
FAO http://www.fao.org/agriculture [Accessed Nov, 20th, 2015]

Foley, J. A., 2011.Solutions for a cultivated planet.Nature.478, 337-342

Jana, H., 2013.Problems faced by vegetable growers in using pesticides in Murshidabad district of West Bengal. Indian Journal of Extension Education \& Rural Development.21:1-5

Kundu, R., and Wale, S. 2013.Role of Pesticides and their management: Agrobios Newsletter: XI (8):33- 36.

Lal, O.P., 2001.Biodiversity in Relation to Insect Pest Management. In proceeding of National Conference on plant protection new horizon in a millennium held at Udaipur during Feb, 23-25:1516.

Latha, P., and Natrajan C.2010.Importance of Biological Control in Agriculture: Agrobios Newsletter; Vol.IX, Issue No.1

Meena, M.L., and Dudi, A.2014.Indigenous technological practices followed by wheat growers in Rajasthan. Indian Journal of Extension Education \& Rural Development. 22:30-35

Peshin, R., Kranthi, K.R. and Sharma, R. 2014. Pesticide use and experiences with Integrated Pest Management Programs and Bt cotton in India. In: Peshin, R. and Pimentel, D. (Eds) Integrated Pest Management:
Experiences with Implementation: Global overview Vol.4, Springer, Dordrecht. The Netherlands.pp269-306 Ragasa, C., Dankyi, A., Acheampong, P., Wiredu, A. N., Wiredu, A., Asamoah, M. and Tripp, R. 2013.Patterns of Adoption of Improved Rice Technologies in Ghana. Working paper, International Food Policy Research Institute (IFPRI).

Rather, S.A., Deo, I., Hussain, A. and Shankar, G.2015 Smart Breeding-a way Forward to Sustainable Agriculture. Paper presented in 4th J\&K Agricultural science Congress.28-30 Oct, SKUAST-Jammu

Sheikh, A. D., Mahmood, M. A., Bashir, A. and Kashif, M. 2006. Adoption of rice technological package by farmers of irrigated Punjab. Journal of Agriculture Research, 44(4): 341-352.

Snelder, D. J., Masipiqueña, M. D and De Snoo, G. R. 2008. Risk assessment of pesticide usage by smallholder farmers in the Cagayan Valley (Philippines). Crop Protection, 27, 747-762.

Trag, A.R., and RatherAG.2013.Food security scenario in Kashmir (India). International Conference of Technology \& Business Management.pp.1017-1023, Islamic Univ. of Science \&Technology, Kashmir.

\section{How to cite this article:}

Rakesh Kumar, Pawan Kumar Sharma, P.S. Slathia and Nishi Sharma. 2017. Pesticide Use in Cereals: An Analysis of Farmers' Perception and Knowledge in Jammu District. Int.J.Curr.Microbiol.App.Sci. 6(10): 2411-2419. doi: https://doi.org/10.20546/ijcmas.2017.610.284 